Sains Malaysiana 50(1)(2021): 23-33

http://dx.doi.org/10.17576/jsm-2021-5001-03

\title{
Involvement of Phenolic Compounds and Their Composition in the Defense Response of Fusarium oxysporum infected Berangan Banana Plants
}

(Penglibatan Sebatian Fenolik dan Komposisinya dalam Tindak Balas Pertahanan Pokok Pisang Berangan yang dijangkiti Fusarium oxysporum)

Fung SHI Ming, ZULiAna RAZALI \& CHANDRAN SOMASUNDRAM*

\begin{abstract}
Fusarium wilt is one of the most common destructive banana diseases which causes great losses to the global banana production. Berangan banana, known to be very susceptible towards this disease is greatly affected. Upon infection, oxidative burst involving rapid accumulation of reactive oxygen species is one of the first responses of a plant defense against biotic and abiotic stress. Secondary metabolites play an essential role in scavenging these toxic reactive radicals. In this study, a number of phenolic compounds and flavonoids were identified and the changes were documented. Compounds such as quinic acid, ferulic acid, caffeoyl glucose, p-coumaric acid, syringic acid, sinapic acid, aconitic acid, caffeic acid, p-hydroxybenzoic acid, ascorbic acid, kaempferol-rhamnose-hexose, quercetin, catechin, rutin, and isorhamnetin 3-O rutinoside increased after fungal infection. Concomitantly, DPPH radical scavenging activity, reducing power, total antioxidant activity, total flavonoid content and total polyphenol content also increased. Polyphenols, flavonoid content and antioxidant activities increased significantly on day 1 and continued to increase until day 6 before gradually declining. The phenolic and flavonoid profiles were analysed using liquid chromatography - mass spectroscopy (LCMS). The antioxidant properties were found to be closely related to plant defense system.
\end{abstract}

Keywords: Antioxidant properties; Berangan banana; flavonoid; Fusarium wilt; phenolics

ABSTRAK

Kelayuan fusarium merupakan salah satu penyakit pisang yang seringkali menyebabkan kerugian besar dalam pengeluaran pisang di peringkat dunia. Pisang Berangan yang diketahui sangat rentan kepada penyakit ini adalah sangat terkesan dengan penyakit tersebut. Selepas dijangkiti, tekanan oksidatif yang melibatkan pengumpulan spesies oksigen reaktif dengan pantas merupakan salah satu tindak balas pertama pertahanan tumbuhan terhadap tekanan biotik dan abiotik. Metabolit sekunder memainkan peranan yang amat penting dalam memerangkap radikal reaktif toksik ini. Dalam kajian ini, sebilangan sebatian fenolik dan flavonoid telah dikenal pasti dan perubahannya telah didokumentasikan. Sebatian seperti asid kuinik, asid ferulik, glukosa kaffeoil, asid p-koumarik, asid syringik, asid sinapik, asid akonitik, asid kafeik, asid p-hidroksibenzoik, asid askorbik, kaempferol-rhamnosa-heksosa, quercetin, katechin, rutin dan isorhamnetin 3-O rutinosid didapati meningkat selepas jangkitan kulat. Seiring dengan itu, aktiviti pembersihan radikal DPPH, daya penurunan, aktiviti antioksidan total, kandungan flavonoid total dan kandungan polifenol juga meningkat. Polifenol, kandungan flavonoid dan aktiviti antioksidan meningkat secara signifikan pada hari pertama selepas jangkitan kulat dan terus meningkat sehingga hari keenam sebelum menurun secara beransur-ansur. Profil fenolik dan flavonoid dianalisis menggunakan kromatografi cecair-spektroskopi massa (LCMS). Sifat antioksidan yang dicerap didapati berkait rapat dengan sistem pertahanan tumbuhan.

Kata kunci: Fenolik; flavonoid; Fusarium wilt; pisang Berangan; sifat antioksidan

\section{INTRODUCTION}

Banana (Musa spp.) is the most important fruit crop and one of the top ten crops by production (Paul et al. 2017). It is also ranked the number four important crop after wheat, maize and rice (Englberger et al. 2003). According to the statistics by the Food and Agricultural Organization of the United Nations (FAO), banana is the second most widely cultivated fruit in Malaysia (FAO 2014), and consists of different cultivars such as Pisang Abu, Pisang Rastali, Pisang Berangan, and Pisang Nangka. Among these cultivars, Berangan banana is the most popular dessert banana and about $50 \%$ of the banana plantation in Malaysia are cultivated with Berangan banana plants. 
Panama disease, commonly known as Fusarium wilt is caused by a soil-borne pathogen Fusarium oxysporum f. sp. cubense (FOC). This disease is the top threat to the global banana production which is worth $\$ 36$ billion (FAO 2014) and affects most of the banana cultivars. Furthermore, the pathogenic strain FOC, tropical race 4 (TR 4) was discovered and identified in Southeast Asia region in 1992 (Robertson 2014) which later became a great concern when the presence of TR 4 was announced in Africa and subsequently in Latin America in November 2013. In Malaysia, the strain was found to affect the Berangan (AAA) cultivar the most (FAO 2016). It is a vascular wilt disease where the pathogens invade the plants through root penetration followed by colonisation of the vascular bundle (Li et al. 2013). Following infection by FOC, infected plants show symptoms such as yellowing and necrosis of the older leaves, vascular discoloration and the splitting of the pseudostem base.

Oxidative burst, the rapid accumulation of reactive oxygen species (superoxide anions, hydroxyl radicals, singlet oxygen, hydrogen peroxide) is one of the earliest response of plant defense after pathogen invasion (Torres et al. 2006). Accumulation of reactive oxygen species (ROS) can cause death to pathogens as well as healthy plant cells. Thus, ROS homeostasis must be monitored. Plants produce a large amount of secondary metabolites which have no direct function in plant growth and development. However, they are proven to have antioxidant properties and play an essential role in plant defense system (Hartmann 1991). These antioxidants especially flavonoids were proven to have radicals scavenging abilities (Mierziak et al. 2014).

Among the phenolics, phytoalexins possess antibiotic and antifungal properties and are produced when the plants are under pathogen attack (Mazid et al. 2011). Phytoalexins can disrupt the pathogen metabolism and the cell structure. Flavonoids are cytotoxic and protect the plants from insects by changing the behaviour, growth and development of the insects. Furthermore, flavonoids are capable of scavenging the ROS and reducing the formation by chelating the metal ions (Simmonds 2003; Treutter 2006). Lignins are the precursors for cell wall thickening and thus provide stronger physical barrier against pathogen attack and reduce the feeding by herbivores (Johnson et al. 2009). Production of furanocoumarins are also induced in response to pathogen or pest attack where these compounds can be highly toxic due to their integration into DNA which contributes to rapid cell death.

The current disease management is by chemical control and unfortunately is not effective enough in preventing this disease. It is crucial to understand how plants respond to this infection in order to develop an effective solution. Although some studies have reported the involvement of secondary metabolites in the defense response of resistant cultivars, there is still a need to look into specific cultivars that are susceptible to the disease. Hence, the purpose of this research is to investigate the involvement of phenolic and antioxidant properties in different parts of the susceptible Berangan banana plant. The data provided by this study will give insight into the defense response of this susceptible cultivar and serve as a platform to further develop an effective solution for this dreadful disease.

\section{MATERIALS AND METHOdS}

\section{SAMPLE PREPARATION - PLANT GROWTH AND INOCULATION PROCEDURE}

Two-month-old Berangan banana plants (Musa, AAA) were purchased from Granatech and stored in a glasshouse in University of Malaya, Malaysia. The FOC strain (race 4), C1HIR_9889 used in this experiment was obtained from Center for Research in Biotechnology for Agriculture (CEBAR), University of Malaya. The C1HIR_9889 was cultured in Yeast Potato Dextrose (YPD) broth in conical flasks. The flasks were left on a rotary shaker at $130 \mathrm{rpm}$ for seven days before they were used to infect the banana plants (Srivastava et al. 2011). The banana plants were removed from the polybags and the roots were soaked in the FOC suspension, with a concentration of $10^{6}$ conidia/mL for an hour (Purwati et al. 2008). The plants were replanted and harvested at intervals of $1,2,4,6,8$, and 10 days following infection and stored in a $-20{ }^{\circ} \mathrm{C}$ freezer prior to extraction. Each plant part which includes roots, pseudostems and leaves were ground into fine powder in a mortar and pestle with liquid nitrogen.

\section{EXTRACTION OF PHENOLIC COMPOUNDS}

Methanol extraction was carried out according to $\mathrm{Xu}$ et al. (2008) with slight modifications. Plant samples were mixed with $80 \%$ methanol solution in $1: 1$ ratio. The mixture was placed in a shaking incubator at $250 \mathrm{rpm}$ for $30 \mathrm{~min}$ at room temperature. The mixture was then centrifuged and the supernatant was used for antioxidant activity analysis.

\section{DETERMINATION OF PHENOLIC COMPOUNDS}

The 1,1-diphenyl-2-picrylhydrazyl (DPPH) radicals scavenging assay was performed following the protocols described by Bae and Suh (2007). Sample extract (0.5 $\mathrm{mL}$ ) was mixed with $1 \mathrm{~mL}$ of $80 \%$ methanolic $0.1 \mathrm{mM}$ DPPH solution. The mixture was put to vortex for $15 \mathrm{~s}$ and incubated under $37^{\circ} \mathrm{C}$ in the dark for $30 \mathrm{~min}$. The absorbance was then measured at $517 \mathrm{~nm}$ by using spectrophotometer.

Reducing power assay was carried out based on Oyaizu (1986) with modifications. Sample extract (50 $\mu \mathrm{L}$ ) was mixed with $200 \mu \mathrm{L}$ of $0.2 \mathrm{M}$ phosphate buffer (pH 6.6) and $200 \mu \mathrm{L}$ of $1 \%$ potassium ferricyanide. The 
mixture was left for 20 min under $50{ }^{\circ} \mathrm{C}$ before $250 \mu \mathrm{L}$ of $10 \%$ trichloroacetic acid was added. The mixture was centrifuged at $1000 \mathrm{rpm}$ for $5 \mathrm{~min}$ under room temperature. Then, $500 \mu \mathrm{L}$ of supernatant was mixed with $500 \mathrm{uL}$ of deionized water and $100 \mu \mathrm{L}$ of $0.1 \%$ ferric chloride. The mixture was left for $5 \mathrm{~min}$ under room temperature before the absorbance was measured at $700 \mathrm{~nm}$.

\section{TOTAL ANTIOXIDANT CAPACITY}

The method reported by Bae and Suh (2007) was referred to determine the total antioxidant capacity. Sample extract $(0.1 \mathrm{~mL})$ was mixed with the $1 \mathrm{~mL}$ of reaction mixture containing $0.6 \mathrm{M}$ sulfuric acid, $28 \mathrm{mM}$ sodium phosphate and $4 \mathrm{mM}$ ammonium molybdate. Then, it was incubated in $95^{\circ} \mathrm{C}$ water bath for $90 \mathrm{~min}$. After the mixture was cooled down to room temperature, the absorbance was measured at $695 \mathrm{~nm}$. A standard curve of ascorbic acid (y $\left.=10.145 \mathrm{x}, \mathrm{r}^{2}=0.9907\right)$ was prepared for 1,1-diphenyl2-picrylhydrazyl (DPPH) radicals scavenging activity, reducing power assay and total antioxidant capacity activities. The results were expressed in micrograms of ascorbic acid equivalent (AAE) per mL sample extract.

\section{TOTAL FLAVONOID CONTENT}

Protocols described by Sakanaka et al. (2005) was referred in order to determine the total flavonoid content. Sample extract $(0.25 \mathrm{~mL})$ was mixed with $1.25 \mathrm{~mL}$ of distilled water and $75 \mu \mathrm{L}$ of $5 \%$ sodium nitrite solution. The mixture was left for 6 min then $150 \mu \mathrm{L}$ of $10 \%$ aluminium chloride solution was added in. The mixture was left for another $5 \mathrm{~min}$ before $0.5 \mathrm{~mL}$ of $1 \mathrm{M}$ of sodium hydroxide was added. The mixture was made up to 2.5 $\mathrm{mL}$ with distilled water and vortexed thoroughly before the absorbance reading was taken at $510 \mathrm{~nm}$. A standard curve of $(+)$-catechin $\left(y=10.145 x, r^{2}=0.9907\right)$ was prepared and the results were expressed in micrograms of catechin equivalent (AAE) per $100 \mathrm{~mL}$ sample extract.

\section{FOLIN-CIOCALTEU ASSAY}

Total phenolic content (Folin-Ciocalteu assay) was modified from Bae and Suh (2007). Distilled water (0.79 $\mathrm{mL}$ ) was mixed with $0.01 \mathrm{~mL}$ of sample extract and 0.05 $\mathrm{mL}$ of Folin-Ciocalteu reagent. The mixture was left for $1 \mathrm{~min}$ before $0.15 \mathrm{~mL}$ of $20 \%$ sodium carbonate was added into the mixture. It was incubated under room temperature in the dark for $120 \mathrm{~min}$. Then, the absorbance was measured at $750 \mathrm{~nm}$. A standard curve of gallic acid (y $=10.145 \mathrm{x}, \mathrm{r}^{2}=0.9907$ ) was prepared and the results were expressed in micrograms of gallic acid equivalent (GAE) per $100 \mathrm{~mL}$ sample extract.

\section{LIQUID CHROMATOGRAPHY-MASS SPECTROMETRY (LCMS/MS)}

To perform LCMS/MS analysis, samples were extracted according to the method by Belajova and Suhaj (2004) and Santhirasegaram et al. (2015) with slight modifications. One part of ground sample was added to two parts of $80 \%$ methanol. The mixture was placed in a shaking incubator at $250 \mathrm{rpm}$ for $30 \mathrm{~min}$ at room temperature, and then centrifuged. The supernatant of the centrifuged sample was collected and filtered through a $0.22 \mu$ m nylon membrane filter.

The extract was injected into the liquid chromatography tandem mass spectrometry (LCMS/ MS) system (AB Sciex 3200QTrap LCMS/MS, MA, USA) coupled to ultra-high-performance liquid chromatography (UHPLC) system (Perkin Elmer Flexar FX15, MA, USA). The column used was Phenomenex Aqua $\mathrm{C}_{18}-50 \mathrm{~mm} \times 2.1 \mathrm{~mm} \times 5 \mu \mathrm{M}$ (CA, USA). Negative ionisation mode was selected for scanning based on preliminary studies. Gradient elution was performed using water with $0.1 \%$ formic acid and $5 \mathrm{mM}$ ammonium formate (buffer B) at flow rate of $800 \mu \mathrm{L} / \mathrm{min}$. The gradient run programme was as follows: $10 \% \mathrm{~A}$ and $90 \% \mathrm{~B}$ at 0.01 to $8 \mathrm{~min}$, then held for $3 \mathrm{~min}$, and back to $10 \% \mathrm{~A}$ at 0.1 $\mathrm{min}$, and re-equilibrated for $5 \mathrm{~min}$. Rapid screening was performed at 15-min run time.

\section{STATISTICAL ANALYSIS}

Data obtained were subjected to statistical analysis using SPSS 21.0 software (SPSS Ins., IBM). The significant differences between mean values of the roots, pseudostems and leaves samples were determined by analysis of variance (one way-ANOVA) using Tukey's HSD test at a significant level of $\mathrm{p}<0.05$.

\section{RESULTS AND DISCUSSION}

Results from our study showed that the phenolic and flavonoid contents as well as the antioxidant activities in infected plants were higher than the healthy plants. The phenolic content (Figure 1(A)) increased significantly at day 1 upon infection and continued to increase thereafter with the highest concentration recorded on day 6 . The increment was $362.5,263.1$ and $274 \%$ for roots, pseudostems and leaves, respectively, compared to the healthy plants. The flavonoid content (Figure 1(B)) increased significantly and the highest concentration was on day 6 with an increase of 206.7, 222.26, and 184.9\% for roots, pseudostems, and leaves, respectively. Phenolics and flavonoids initially accumulated in the roots as the roots are the pathogen attacking site. FOC is known to invade the plant through root opening such as wounds or zone of differentiation. Phenolic acids are monomers for lignin which is an important component for cell wall thickening. Accumulation of phenolic acids at the pathogen attacking sites induce thickening of cell wall to inhibit pathogen entry (Huckelhoven 2007). Invasion of the pathogen FOC into berangan banana plants seem to have stimulated the plant defense system subsequently inducing ROS formation. Similarly, Li et al. (2013) observed an accumulation of hydrogen peroxide in 
banana roots infected by Fusarium. ROS homoeostasis must be monitored as it can bring both beneficial and deleterious effects to the host plants. Since phenolics and flavonoids have antioxidant, antimicrobial and antifungal properties (War et al. 2012), the high amount of phenolics is usually accompanied by high antioxidant and radical scavenging activities. Total antioxidant activities (Figure 1(D)) increased by 151.77, 107.1, and 105.71\% for roots, pseudostems, and leaves while the reducing power assay (Figure 1(E)) increased by 129.8, 103.59, and $97.89 \%$, respectively. These activities were highest on day 6 before declining where these patterns were similar to the phenolic and flavonoid content changes. Quercetin, a flavanoid, inhibits ROS production by acting as an inhibitor of oxygen activating enzymes such as xanthinoxidase (Mierziak et al. 2014) which makes quercetin important to keep ROS levels in equilibrium to avoid over accumulation of ROS and cell death (Tripathy \& Oelmüller 2012). Increasing phenolics and flavonoid levels were accompanied by increasing DPPH activities where the value increased by $98.2 \%$ in roots, $87.9 \%$ in pseudostems and $90.3 \%$ in leaves.

Based on the LCMS/MS analysis, different types of phenolic compounds were identified and increased in concentration in different plant parts after fungal infection (Figure 2). Among the phenolic acids identified were quinic acid, ferulic acid, caffeoyl glucose, p-coumaric acid, syringic acid, sinapic acid, aconitic acid, caffeic acid, p-hydroxybenzoic acid and ascorbic acid while for flavonoids were kaempferol-rhamnose-hexose, quercetin, catechin, rutin and isorhamnetin 3-O rutinoside (Tables 1-6). de Ascensao and Dubery (2003) identified and quantified a number of phenolics compounds (benzoic acid, p-coumaric acid, sinapic aicd and ferulic acid) from Fusarium infected 'Goldenfinger' banana roots which were compounds that had been similarly identified in our study. However, several compounds including protocatechuic, vanillic, syringic, cinnamic and caffeic acid found in infected 'Goldenfinger' banana were not detected in Berangan. This suggested that the defense mechanism incorporates various combinations of antioxidative compunds that may be cultivar specific. A number of studies have also reported upregulation of phenolic compound synthesis genes in Fusarium infected bananas. Although synthesis of defense compounds is upregulated, bananas like Berangan are still susceptible to FOC. A transcriptomic study carried out on the resistant Pahang banana cultivar suggested that resistance may be conferred due to the constitutive expression of defense related genes including antioxidants, even prior to inoculation and infection (Zhang et al. 2019) as opposed to what was observed in Berangan.

A.

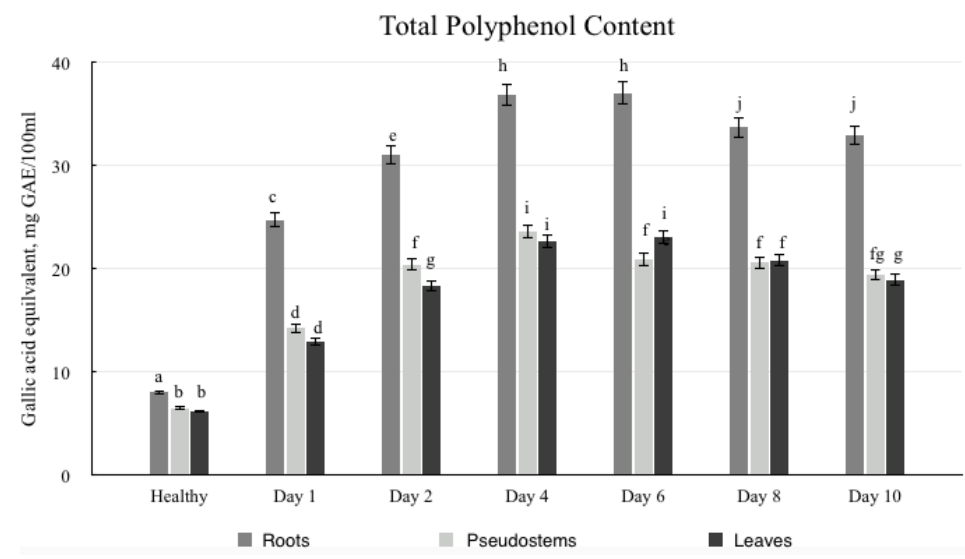

Total Flavonoid Content

B.

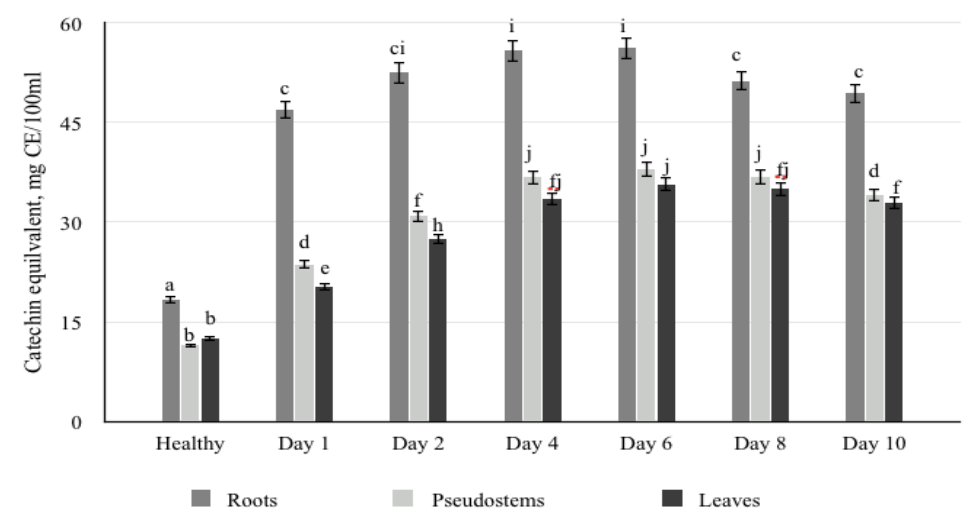


C. DPPH radical scavenging activity

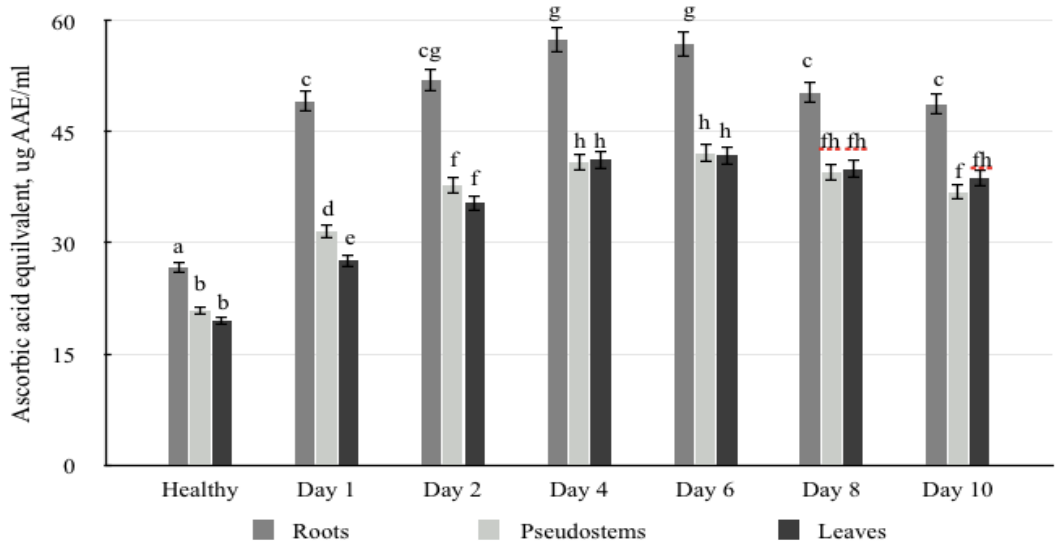

D.

Total Antioxidant Capacity

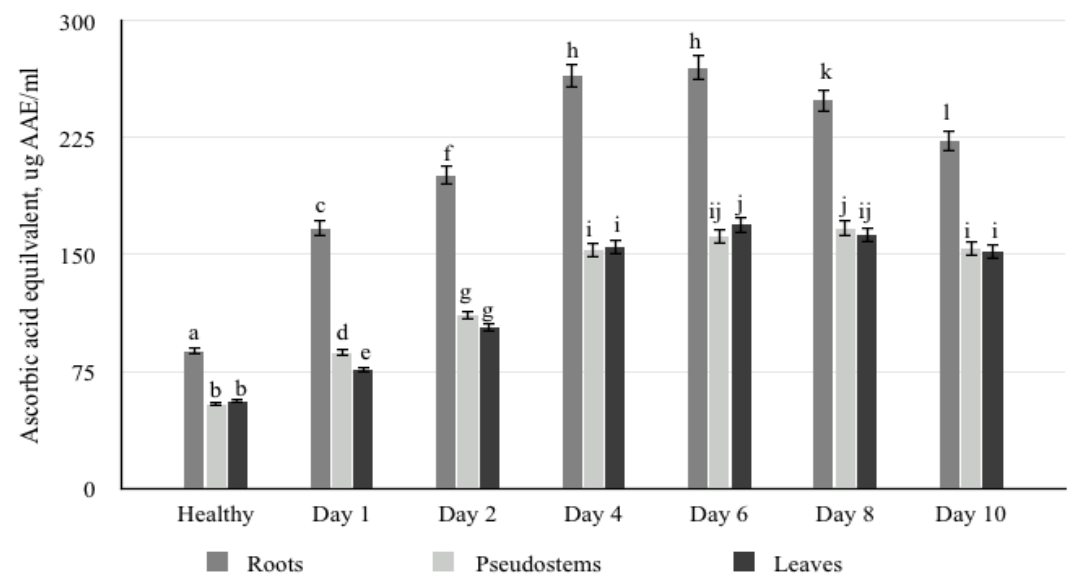

E.

Reducing Power Assay

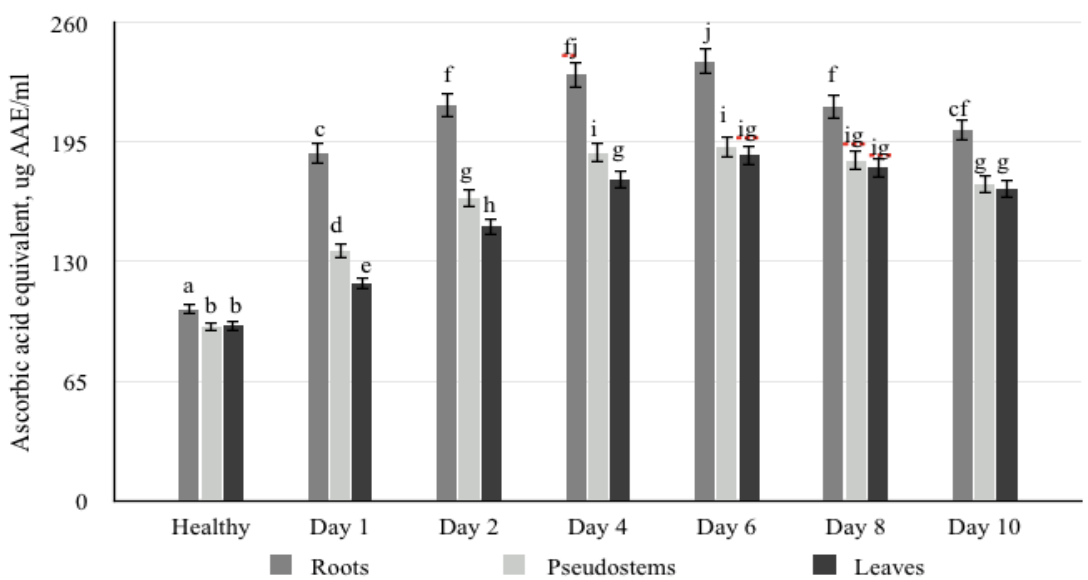

FIGURE 1. (A) Total polyphenol content; (B) Total flavonoid content; (C) DPPH radical scavenging activity; (D) Total antioxidant capacity and (E) Reducing power assay in healthy and infected plants harvested at different intervals 

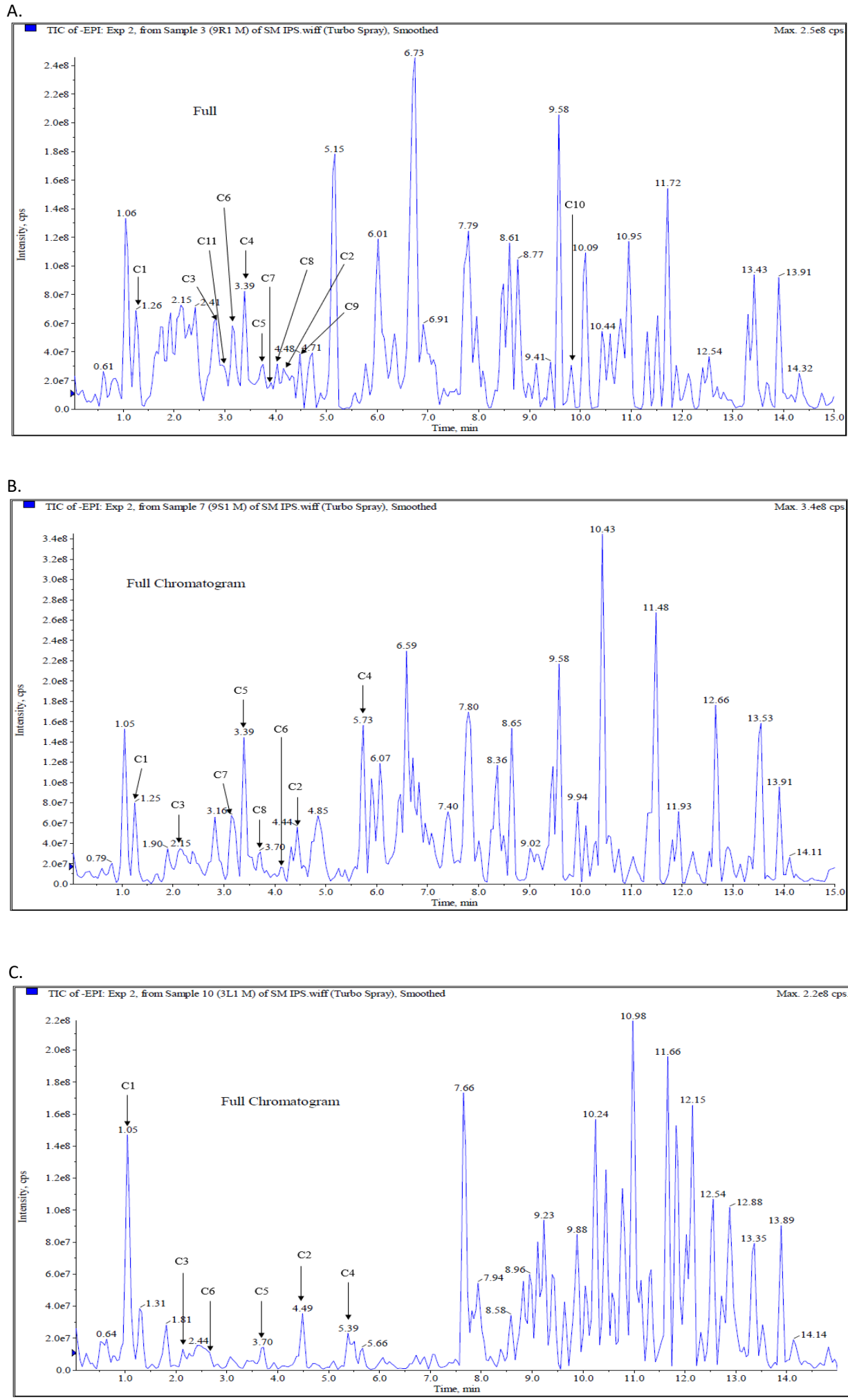

FIGURE 2. Liquid Chromatography-Mass Spectrometry (LCMS/MS) full chromatogram of banana roots (A), pseudostems (B) and leaves (C) 
In our study, there was an elevation of $p$-coumaric $\left(138.93 \pm 1.4^{\mathrm{c}} \mathrm{mg} / 100 \mathrm{~mL}\right)$ in infected roots and ferulic acid $\left(128.52 \pm 2.59^{\mathrm{d}} \mathrm{mg} / 100 \mathrm{~mL}\right)$ in infected pseudostems which was in line with the findings of Kalisz et al. (2015). Furthermore, caffeic acid which has been proven to have phytotoxic effect on fungal growth also increased in the infected plant parts and recorded the highest concentration of $180.94 \pm 2.05^{\mathrm{d}} \mathrm{mg} / 100 \mathrm{~mL}$ in infected leaves on day 6 . On the contrary, results from our study showed that all phenolic compounds including caffeic acid increased at the early stage of infection but decreased at the later phase of infection. The decline in phenolic compounds was a clear indication that the plants were losing their antioxidant capacity. This would lead to over accumulation of ROS and finally necrosis. Mierziak et al. (2014) stated that quercetin is one of the most powerful ROS scavengers among flavonoids. In our study, quercetin and catechin had been identified in the infected roots where ROS accumulation first occurred. Quercetin and catechin showed the highest concentrations, $114.2 \pm 1.41^{\mathrm{c}}$ $\mathrm{mg} / 100 \mathrm{~mL}$ and $120.4 \pm 0.6^{\mathrm{c}} \mathrm{mg} / 100 \mathrm{~mL}$, respectively, on day 4 in infected roots. Among the flavonoids, flavonol triglycoside of kaempferide, kaempferol O-rutinoside, kaempferol-3-O- $\beta$-D-glucopyranosyl, isoorientin, isovitexin and vixetin were useful antifungal agent against $F$. oxysporum (Mierziak et al. 2014). Our results were in line with their findings as we had identified some of the flavonoid compounds such as kaempferolrhamnose-hexose $\left(190.1 \pm 1.05^{\mathrm{d}} \mathrm{mg} / 100 \mathrm{~mL}\right)$ from the banana leaves.

In Berangan bananas, accumulation of phenolic compounds was not limited to roots but was also observed in the pseudostems and leaves. However, the increments in pseudostems and leaves was slower and were not as high as in the roots. As the root was the pathogen attacking site, accumulation of phenolic compounds and elevation of antioxidant activities occurred in the roots first. This result was in agreement with the findings reported by Anthony et al. (2017) where they reported higher antioxidant activities in infected roots, pseudostems and leaves. FOC which has penetrated through the roots will continue to grow and colonise the vascular bundle. The growing hyphae will eventually block the vascular bundle and restrict the water and nutrient transport (Vishwanath et al. 2011). This would introduce abiotic stress to the plants and eventually cause necrosis. Following necrosis, plant metabolism and synthesis of the secondary metabolites will be disrupted resulting in the reduction of phenolic compounds. This was evident in our study, where the concentration of phenolic compounds significantly reduced at the later stage of infection in all parts of the plants (Tables 4-6). This in turn led to lower antioxidant and radicals scavenging activities.

TABLE 1. Retention time and mass spectrometric data of phenolic compounds in Berangan banana roots determined by LCMS/MS analysis

\begin{tabular}{|c|c|c|c|c|c|}
\hline $\begin{array}{l}\text { Retention time } \\
\qquad(\min )\end{array}$ & {$[\mathrm{M}-\mathrm{H}]^{-}(\mathrm{m} / \mathrm{z})$} & MS/MS (m/z) & $\begin{array}{l}\text { Molecular } \\
\text { formula }\end{array}$ & Assigned identity & Class \\
\hline 1.25 & 191.3 & $191,127,84.9$ & $\mathrm{C}_{7} \mathrm{H}_{12} \mathrm{O}_{6}$ & Quinic acid & Phenolic acid \\
\hline 4.15 & 193.09 & $193,178,134$ & $\mathrm{C}_{10} \mathrm{H}_{10} \mathrm{O}_{4}$ & Ferulic acid & Phenolic acid \\
\hline 2.9 & 341.24 & $341,161,179$ & $\mathrm{C}_{15} \mathrm{H}_{18} \mathrm{O}_{9}$ & Caffeoyl glucose & Phenolic acid \\
\hline 3.4 & 285.25 & $211,187,158$ & $\mathrm{C}_{15} \mathrm{H}_{10} \mathrm{O}_{6}$ & $\begin{array}{l}\text { Kaempferol-rhamnose- } \\
\text { hexose }\end{array}$ & Flavonoid \\
\hline 3.71 & 301.23 & $230,152,136$ & $\mathrm{C}_{15} \mathrm{H}_{10} \mathrm{O}_{7}$ & Quercetin & Flavonoid \\
\hline 3.14 & 289.02 & $289,245,203.1$ & $\mathrm{C}_{15} \mathrm{H}_{14} \mathrm{O}_{6}$ & Catechin & Flavonoid \\
\hline 3.96 & 163.09 & $163,147,119$ & $\mathrm{C}_{9} \mathrm{H}_{8} \mathrm{O}_{3}$ & p-Coumaric acid & Phenolic acid \\
\hline 4.08 & 609.42 & $299.9,271,256$ & $\mathrm{C}_{27} \mathrm{H}_{30} \mathrm{O}_{16}$ & Rutin & Flavonoid \\
\hline 4.45 & 623.34 & $315,298.9,271.1$ & $\mathrm{C}_{28} \mathrm{H}_{32} \mathrm{O}_{16}$ & $\begin{array}{l}\text { Isorhamnetin 3-O } \\
\text { rutinoside }\end{array}$ & Flavonoid \\
\hline 9.89 & 198 & $197,182,153$ & $\mathrm{C}_{9} \mathrm{H}_{10} \mathrm{O}_{5}$ & Syringic acid & Phenolic acid \\
\hline 3.2 & 224.21 & $223.1,205.2,153.1$ & $\mathrm{C}_{11} \mathrm{H}_{12} \mathrm{O}_{5}$ & Sinapic acid & Phenolic acid \\
\hline
\end{tabular}


TABLE 2. Retention time and mass spectrometric data of phenolic compounds in Berangan banana pseudostems determined by LCMS/MS analysis

\begin{tabular}{cccccc}
\hline $\begin{array}{c}\text { Retention time } \\
(\mathrm{min})\end{array}$ & {$[\mathrm{M}-\mathrm{H}]^{-}(\mathrm{m} / \mathrm{z})$} & $\mathrm{MS} / \mathrm{MS}(\mathrm{m} / \mathrm{z})$ & $\begin{array}{c}\text { Molecular } \\
\text { formula }\end{array}$ & Assigned identity & Class \\
\hline 1.25 & 191.3 & $191,127,84.9$ & $\mathrm{C}_{7} \mathrm{H}_{12} \mathrm{O}_{6}$ & Quinic acid & Phenolic acid \\
2.15 & 173.19 & $173,155,111$ & $\mathrm{C}_{6} \mathrm{H}_{6} \mathrm{O}_{6}$ & Aconitic acid & Phenolic acid \\
2.9 & 341.24 & $341,161,179$ & $\mathrm{C}_{15} \mathrm{H}_{18} \mathrm{O}_{9}$ & Caffeoyl glucose & Phenolic acid \\
5.71 & 803.2 & $161,133,88.9$ & $\mathrm{C}_{9} \mathrm{H}_{8} \mathrm{O}_{4}$ & Caffeic acid & Phenolic acid \\
3.39 & 355.37 & $193.1,175.1,160.1$ & $\mathrm{C}_{16} \mathrm{H}_{20} \mathrm{O}_{9}$ & Ferulic acid glucoside & Phenolic acid \\
4.08 & 609.42 & $299.9,271,256$ & $\mathrm{C}_{27} \mathrm{H}_{30} \mathrm{O}_{16}$ & Rutin & Flavonoid \\
3.2 & 224.21 & $223.1,205.2,153.1$ & $\mathrm{C}_{11} \mathrm{H}_{12} \mathrm{O}_{5}$ & Sinapic acid & Phenolic acid \\
3.70 & 137.09 & 137,108 & $\mathrm{C}_{7} \mathrm{H}_{6} \mathrm{O}_{3}$ & p-hydroxybenzoic & Phenolic acid \\
\hline
\end{tabular}

TABLE 3. Retention time and mass spectrometric data of phenolic compounds in Berangan banana leaves determined by LCMS/MS analysis

\begin{tabular}{lccccc}
\hline $\begin{array}{c}\text { Retention time } \\
(\mathrm{min})\end{array}$ & {$[\mathrm{M}-\mathrm{H}]^{-}(\mathrm{m} / \mathrm{z})$} & MS/MS $(\mathrm{m} / \mathrm{z})$ & $\begin{array}{c}\text { Molecular } \\
\text { formula }\end{array}$ & Assigned identity & Class \\
\hline 1.05 & 191.3 & $191,127,84.9$ & $\mathrm{C}_{7} \mathrm{H}_{12} \mathrm{O}_{6}$ & Quinic acid & Phenolic acid \\
4.49 & 193.09 & $193,178,134$ & $\mathrm{C}_{10} \mathrm{H}_{10} \mathrm{O}_{4}$ & Ferulic acid & Phenolic acid \\
2.09 & 341.24 & $341,161,179$ & $\mathrm{C}_{15} \mathrm{H}_{18} \mathrm{O}_{9}$ & Caffeoyl glucose & Phenolic acid \\
5.31 & 803.2 & $161,133,88.9$ & $\mathrm{C}_{9} \mathrm{H}_{8} \mathrm{O}_{4}$ & Caffeic acid & Phenolic acid \\
3.7 & 285.25 & $211,187,158$ & $\mathrm{C}_{15} \mathrm{H}_{10} \mathrm{O}_{6}$ & $\begin{array}{c}\text { Kaempferol- } \\
\text { rhamnose-hexose }\end{array}$ & Flavonoid \\
2.54 & 175.24 & $175.1,157.1,115.1$ & $\mathrm{C}_{6} \mathrm{H}_{8} \mathrm{O}_{6}$ & Ascorbic acid & Phenolic acid \\
\hline
\end{tabular}

TABLE 4. Phenolic compounds content in healthy and infected roots harvested at different intervals

\begin{tabular}{|c|c|c|c|c|c|c|c|c|c|c|c|}
\hline & \multicolumn{11}{|c|}{ Relative concentration of phenolic compounds $(\mathrm{mg} / 100 \mathrm{~mL})$} \\
\hline & $\mathrm{C} 1$ & $\mathrm{C} 2$ & $\mathrm{C} 3$ & $\mathrm{C} 4$ & $\mathrm{C} 5$ & C6 & $\mathrm{C} 7$ & $\mathrm{C} 8$ & C9 & $\mathrm{C} 10$ & C11 \\
\hline Healthy & $\begin{array}{c}48.7 \pm \\
2.41^{\mathrm{a}}\end{array}$ & $\begin{array}{c}16.21 \pm \\
1.06^{\mathrm{e}}\end{array}$ & $\begin{array}{c}121.1 \pm \\
3.48^{\mathrm{d}}\end{array}$ & $\begin{array}{c}52.97 \pm \\
2.55^{\mathrm{a}}\end{array}$ & $\begin{array}{l}57.7 \pm \\
2.98^{\mathrm{ab}}\end{array}$ & $\begin{array}{c}43.3 \pm \\
2.07^{\mathrm{a}}\end{array}$ & $\begin{array}{c}51.84 \pm \\
2.08^{\mathrm{a}}\end{array}$ & $\begin{array}{c}41.24 \pm \\
1.89^{\mathrm{a}}\end{array}$ & $\begin{array}{c}20.9 \pm \\
1.22^{\mathrm{e}}\end{array}$ & $\begin{array}{c}37.73 \pm \\
2.61^{\text {ae }}\end{array}$ & $\begin{array}{c}90.11 \pm \\
1.06^{\mathrm{c}}\end{array}$ \\
\hline Day 1 & $\begin{array}{c}74.51 \pm \\
2.76^{\mathrm{b}}\end{array}$ & $\begin{array}{l}42 \pm \\
1.05^{\mathrm{a}}\end{array}$ & $\begin{array}{c}203.9 \pm \\
4.26^{\mathrm{f}}\end{array}$ & $\begin{array}{c}113.57 \pm \\
1.66^{\mathrm{d}}\end{array}$ & $\begin{array}{c}85.63 \pm \\
3.26^{\mathrm{b}}\end{array}$ & $\begin{array}{c}98.57 \pm \\
1.53^{\mathrm{c}}\end{array}$ & $\begin{array}{c}87.43 \pm \\
2.55^{\mathrm{bc}}\end{array}$ & $\begin{array}{c}60.94 \pm \\
2.03^{\mathrm{b}}\end{array}$ & $\begin{array}{c}48.95 \pm \\
1.66^{\mathrm{a}}\end{array}$ & $\begin{array}{c}63.07 \pm \\
2.17^{\mathrm{ab}}\end{array}$ & $\begin{array}{c}164.1^{ \pm} \\
0.9^{\mathrm{i}}\end{array}$ \\
\hline Day 4 & $\begin{array}{c}94.7 \pm \\
2.35^{\mathrm{c}}\end{array}$ & $\begin{array}{l}79.9 \pm \\
4.06^{\mathrm{b}}\end{array}$ & $\begin{array}{c}274.8 \pm \\
2.8^{\mathrm{g}}\end{array}$ & $\begin{array}{c}159.73 \pm \\
1.62^{\mathrm{i}}\end{array}$ & $\begin{array}{c}114.2 \pm \\
1.41^{\mathrm{d}}\end{array}$ & $\begin{array}{c}120.4 \pm \\
0.6^{\mathrm{d}}\end{array}$ & $\begin{array}{c}135.57 \pm \\
2.23^{\mathrm{di}}\end{array}$ & $\begin{array}{l}87.5 \pm \\
1.52^{\mathrm{bc}}\end{array}$ & $\begin{array}{l}81 \pm \\
2.11^{b}\end{array}$ & $\begin{array}{c}91.38 \pm \\
1.49^{\mathrm{c}}\end{array}$ & $\begin{array}{c}203.07 \pm \\
1.8^{\mathrm{f}}\end{array}$ \\
\hline Day 6 & $\begin{array}{c}121.2 \pm \\
2.88^{\mathrm{d}}\end{array}$ & $\begin{array}{c}80.97 \pm \\
2.63^{b}\end{array}$ & $\begin{array}{c}331.93 \pm \\
1.79^{\mathrm{h}}\end{array}$ & $\begin{array}{c}190.1 \pm \\
1.05^{\mathrm{f}}\end{array}$ & $\begin{array}{c}103.37 \pm \\
2.07^{\mathrm{cd}}\end{array}$ & $\begin{array}{c}114.93 \pm \\
1.2^{\mathrm{d}}\end{array}$ & $\begin{array}{c}138.93 \pm \\
1.4^{\mathrm{di}}\end{array}$ & $\begin{array}{c}109.46 \pm \\
2.7^{\mathrm{d}}\end{array}$ & $\begin{array}{c}100.3 \pm \\
1.82^{\text {cd }}\end{array}$ & $\begin{array}{c}117.26 \pm \\
2.42^{\mathrm{d}}\end{array}$ & $\begin{array}{c}242.22 \pm \\
1.47^{j}\end{array}$ \\
\hline Day 10 & $\begin{array}{c}42.73 \pm \\
1.55^{\mathrm{a}}\end{array}$ & $\begin{array}{c}49.17 \pm \\
1.8^{\mathrm{a}}\end{array}$ & $\begin{array}{c}153.83 \pm \\
1.93^{\mathrm{i}}\end{array}$ & $\begin{array}{c}67.43 \pm \\
2.45^{\mathrm{b}}\end{array}$ & $\begin{array}{c}70.27 \pm \\
1.12^{\mathrm{b}}\end{array}$ & $\begin{array}{c}66.13 \pm \\
2.42^{\mathrm{b}}\end{array}$ & $\begin{array}{l}71.3 \pm \\
1.04^{\mathrm{d}}\end{array}$ & $\begin{array}{l}72.3 \pm \\
2.32^{\mathrm{b}}\end{array}$ & $\begin{array}{c}79.51 \pm \\
1.49^{\mathrm{b}}\end{array}$ & $\begin{array}{c}87.31 \pm \\
2.25^{\mathrm{bc}}\end{array}$ & $\begin{array}{c}130.73 \pm \\
1.98^{\mathrm{d}}\end{array}$ \\
\hline
\end{tabular}

C1 Quinic acid; C2 Ferulic acid; C3 Caffeoyl glucose; C4 Kaempferol-rhamnose-hexose; C5 Quercetin; C6 Catechin; C7 p-Coumaric acid; C8 Rutin; C9 Isorhamnetin 3-O rutinoside; $\mathrm{C} 10$ Syringic acid; C11 Sinapic acid 
TABLE 5. Phenolic compounds content in healthy and infected pseudostems harvested at different intervals

\begin{tabular}{lllllllll}
\hline \multicolumn{7}{c}{ Relative concentration of phenolic compounds $(\mathrm{mg} / 100 \mathrm{~mL})$} \\
& $\mathrm{C} 1$ & $\mathrm{C} 2$ & $\mathrm{C} 3$ & $\mathrm{C} 4$ & $\mathrm{C} 5$ & $\mathrm{C} 6$ & $\mathrm{C} 7$ & $\mathrm{C} 8$ \\
\hline Healthy & $90.1 \pm$ & $32.01 \pm$ & $54.16 \pm$ & $85.62 \pm$ & $50.2 \pm$ & $55.38 \pm$ & $57.75 \pm$ & $44.41 \pm$ \\
& $1.18^{\mathrm{a}}$ & $1.87^{\mathrm{e}}$ & $1.91^{\mathrm{f}}$ & $2.33^{\mathrm{a}}$ & $2.04^{\mathrm{f}}$ & $1.52^{\mathrm{f}}$ & $1.89^{\mathrm{f}}$ & $1.28^{\mathrm{ef}}$ \\
Day 1 & $121.73 \pm$ & $57.97 \pm$ & $110.09 \pm$ & $115.73 \pm$ & $80.35 \pm$ & $78.02 \pm$ & $80.85 \pm$ & $73.97 \pm$ \\
& $2.38^{\mathrm{b}}$ & $1.38^{\mathrm{f}}$ & $1.85^{\mathrm{ab}}$ & $1.77^{\mathrm{b}}$ & $1.44^{\mathrm{ag}}$ & $1.46^{\mathrm{g}}$ & $0.63^{\mathrm{ag}}$ & $1.66^{\mathrm{g}}$ \\
Day 4 & $147.05 \pm$ & $85.35 \pm$ & $151.82 \pm$ & $140.9 \pm$ & $103.98 \pm$ & $101.27 \pm$ & $121.36 \pm$ & $128.55 \pm$ \\
& $1.6^{\mathrm{c}}$ & $2.22^{\mathrm{a}}$ & $1.6^{\mathrm{c}}$ & $1.93^{\mathrm{c}}$ & $2.15^{\mathrm{a}}$ & $1.88^{\mathrm{a}}$ & $0.92^{\mathrm{b}}$ & $1.69^{\mathrm{b}}$ \\
Day 6 & $173.44 \pm$ & $77.28 \pm$ & $211.43 \pm$ & $163.57 \pm$ & $128.52 \pm$ & $130.45 \pm$ & $114.04 \pm$ & $165.05 \pm$ \\
& $1.71^{\mathrm{d}}$ & $2.28^{\mathrm{g}}$ & $0.6^{\mathrm{e}}$ & $2.34^{\mathrm{d}}$ & $2.59^{\mathrm{b}}$ & $2.16^{\mathrm{bc}}$ & $1.79^{\mathrm{b}}$ & $1.73^{\mathrm{d}}$ \\
Day 10 & $100.24 \pm$ & $56.59 \pm$ & $89.65 \pm$ & $119.29 \pm$ & $94.36 \pm$ & $89.26 \pm$ & $72.59 \pm$ & $66.75 \pm$ \\
& $1.15^{\mathrm{a}}$ & $1.51^{\mathrm{f}}$ & $1.46^{\mathrm{a}}$ & $0.92^{\mathrm{b}}$ & $1.47^{\mathrm{a}}$ & $1.59^{\mathrm{a}}$ & $1.08^{\mathrm{g}}$ & $2.23^{\mathrm{g}}$
\end{tabular}

* Mean values followed by different letters within the same column are significantly different $(\mathrm{p}<0.05)(\mathrm{n}=9)$

C1 Quinic acid; C2 Aconitic acid; C3 Caffeoyl glucose; C4 Caffeic acid; C5 Ferulic acid glucoside; C6 Rutin; C7 Sinapic acid; C8 p-hydroxybenzoic acid

TABLE 6. Phenolic compounds content in healthy and infected leaves harvested at different intervals

\begin{tabular}{|c|c|c|c|c|c|c|}
\hline & \multicolumn{6}{|c|}{ Relative concentration of phenolic compounds (mg/100 mL) } \\
\hline & $\mathrm{C} 1$ & $\mathrm{C} 2$ & $\mathrm{C} 3$ & $\mathrm{C} 4$ & C5 & C6 \\
\hline Healthy & $55.73 \pm 1.37^{\mathrm{a}}$ & $47.98 \pm 1.28^{\mathrm{a}}$ & $54.08 \pm 1.83^{\mathrm{a}}$ & $91.47 \pm 2.31^{b}$ & $35.25 \pm 1.53^{\mathrm{g}}$ & $75.12 \pm 1.59^{\mathrm{ab}}$ \\
\hline Day 1 & $85.02 \pm 1.75^{\mathrm{b}}$ & $71.4 \pm 1.05^{\mathrm{ab}}$ & $82.28 \pm 0.88^{b}$ & $127.92 \pm 1.55^{\mathrm{cd}}$ & $52.94 \pm 2.04^{\mathrm{a}}$ & $122.38 \pm 2.23^{\mathrm{c}}$ \\
\hline Day 4 & $104.37 \pm 1.2^{\mathrm{bc}}$ & $97.58 \pm 1.81^{\mathrm{bc}}$ & $118.35 \pm 0.63^{\mathrm{c}}$ & $155.74 \pm 1.75^{\mathrm{e}}$ & $80.75 \pm 1.83^{\mathrm{b}}$ & $203.02 \pm 1.73^{\mathrm{h}}$ \\
\hline Day 6 & $108.62 \pm 1.51^{\mathrm{bc}}$ & $115.55 \pm 1.55^{\mathrm{c}}$ & $134.22 \pm 2.02^{\mathrm{d}}$ & $180.94 \pm 2.05^{\mathrm{f}}$ & $84.28 \pm 1.7^{\mathrm{b}}$ & $239.37 \pm 2.1^{\mathrm{i}}$ \\
\hline Day 10 & $81.58 \pm 0.7^{b}$ & $60.01 \pm 1.13^{\mathrm{a}}$ & $62.15 \pm 2.08^{\mathrm{a}}$ & $143.83 \pm 1.53^{\mathrm{d}}$ & $49.46 \pm 2.36^{\mathrm{a}}$ & $85.56 \pm 1.55^{\mathrm{b}}$ \\
\hline
\end{tabular}

* Mean values followed by different letters within the same column are significantly different $(\mathrm{p}<0.05)(\mathrm{n}=9)$

C1 Quinic acid; C2 Ferulic acid; C3 Caffeoyl glucose; C4 Caffeic acid; C5 Kaempferol-rhamnose-hexose; C6 Ascorbic acid

FOC is a hemibiotroph that behaves as a biotroph at the early stages of infection. Accumulation of ROS at this stage might restrict the FOC development due to the programmed cell death activated by the elevated ROS. Dead host cells deprive FOC of its food source at this stage. ROS can also induce apoptosis effect on FOC by binding to FOC cell membrane components, resulting in FOC cell membrane destruction (Tripathy \& Oelmüller 2012). On the other hand, FOC transforms into a necrotroph at the later stages of infection and preys upon dead cells. Li et al. (2013) had reported that FOC race 4 would secrete fusaric acid (FA) and beauvericin (BEA) when they transformed into necrotroph. These toxins, especially FA have been proven to cause damage to banana cells and protoplasts. The presence of the toxins and blockage of vascular tissue cause damage to the plant cells which eventually lead to necrosis.

\section{CONCLUSION}

This study was the first to use phenolic compounds in studying the Berangan banana defense against FOC. The phenolics and flavonoid compounds in different parts of Berangan banana plants experienced elevation after FOC invasion. Phenolic compounds such as $p$-coumaric, caffeic acid, ferulic acid, quercetin and catechin showed higher concentrations in infected banana plants. This was followed by increased antioxidant activities and 
capabilities which were useful in scavenging the toxic radicals at the infection sites. Although these antioxidant compounds increased at the early stage of infection, they declined at the later phase of infection. The decline in phenolic compounds was a clear indication that the plants were losing their antioxidant capacity. This led to over accumulation of ROS and thus causing necrosis.

\section{ACKNOWLEDGEMENTS}

The authors would like to thank the Biosecurity and Biosafety for Tropical Agricultural Bioeconomy (RU0062017), University of Malaya's Postgraduate Research Fund (PG233-2016A) and the Geran Penyelidikan Universiti Malaya (UMRG Programme) - AET (Innovative Technology (ITRC)) (RP005D-13BIO) for supporting our research.

\section{REFERENCES}

Anthony, K.K., George, D.S., Singh, H.K.B., Fung, S.M., Santhirasegaram, V., Razali, Z. \& Somasundram, C. 2017. Reactive oxygen species activity and antioxidant properties of Fusarium infected bananas. Journal of Phytopathology 165(4): 2213-2222.

Bae, S.H. \& Suh, H.J. 2007. Antioxidant activities of five different mulberry cultivars in Korea. LWT - Food Science and Technology 40(6): 955-962.

Belajova, E. \& Suhaj, M. 2004. Determination of phenolic constituents in citrus juices: Method of high performance liquid chromatography. Food Chemistry 86(3): 339-343.

de Ascensao, A.R.F.D.C. \& Dubery, I.A. 2003. Soluble and wall-bound phenolics and phenolic polymers in Musa acuminata roots exposed to elicitors from Fusarium oxysporum f. sp. cubense. Phytochemistry 63(6): 679-686.

Englberger, L., Darnton-Hill, I., Coyne, T., Fitzgerald, M.H. \& Marks, G.C. 2003. Carotenoid-rich bananas: A potential food source for alleviating vitamin A deficiency. Food and Nutrition Bulletin 24(4): 303-318.

FAO. 2016. WBF fighting against banana threats - WBF Task Force on Fusarium wilt Tropical Race 4 (TR4). http://www. fao.org/economic/worldbananaforum/fusarium.

FAO. 2014. FAO and partners call for a global response to deadly banana disease. http://www.fao.org/news/story/en/ item/271647/icode/.

Hartmann, T. 1991. Alkaloids. In Herbivores: Their Interactions with Secondary Plant Metabolites (2nd edition) - The Chemical Participants, edited by Rosenthal, G.A. \& Berenbaum, M.R. San Diego. pp. 79-121.

Huckelhoven, R. 2007. Cell wall-associated mechanisms of disease resistance and susceptibility. Annual Review of Phytopathology 45: 101-127.

Johnson, M.T.J., Smith, S.D. \& Rausher, M.D. 2009. Plant sex and the evolution of plant defenses against herbivores. Proceeding of the National Academy of Science of the United States of America 106(43): 18079-18084.

Kalisz, S., Oszmianski, J. \& Wojdylo, A. 2015. Increased content of phenolic compounds in pear leaves after infection by the pear rust pathogen. Physiological and Molecular Plant Pathology 91: 113-119.

Li, C., Zuo, C., Deng, G., Kuang, R., Yang, Q., Hu, C., Sheng, Q., Zhang, S., Ma, L., Wei, Y., Yang, J., Liu, S., Biswas, M.K., Viljoen, A. \& Yi, G. 2013. Contamination of bananas with Beauvericin and fusaric acid produced by Fusarium oxysporum f. sp. cubense. PLoS ONE 8(7): e70226.

Mazid, M., Khan, T.A. \& Mohammad, F. 2011. Role of secondary metabolites in defense mechanism of plants. Biology and Medicine 3(2): 232-249.

Mierziak, J., Kostyn, K. \& Kulma, A. 2014. Flavonoids as important molecules of plant interactions with the environment. Molecules 19(10): 16240-16265.

Oyaizu, M. 1986. Studies on products of browning reactions: Antioxidative activities of products of browning reaction prepared from glucosamine. The Japanese Journal of Nutrition and Dietetics 44(6): 307-315.

Paul, J.Y., Khanna, H., Kleidon, J., Hoang, P., Geijskes, J., Daniells, J., Zaplin, E., Rosenberg, Y., James, A., Mlalazi, B., Deo, P., Arinaitwe, G., Namanya, P., Becker, D., Tindamanyire, J., Tushemereirwe, W., Harding, R. \& Dale, J. 2017. Golden bananas in the field: Elevated fruit provitamin A from the expression of a single banana transgene. Plant Biotechnology Journal 15(4): 520-532.

Purwati, R.D., Hidayah, N., Sudjindro \& Sudarsono. 2008. Inoculation methods and conidial densities of Fusarium oxysporum f.sp. cubense in Abaca. HAYATI Journal of Biosciences 15(1): 1-7.

Robertson, A.E. 2014. First report of Fusarium oxysporum f. sp. cubense tropical race 4 associated with Panama disease of banana outside Southeast Asia. Plant Disease 98(5): 694-698.

Sakanaka, S., Tachibana, Y. \& Okada, Y. 2005. Preparation and antioxidant properties of extracts of Japanese persimmon leaf tea (kakinoha-cha). Food Chemistry 89(4): 569-575.

Santhirasegaram, V., Razali, Z., George, D.S. \& Somasundram, C. 2015. Effects of thermal and non-thermal processing on phenolic compounds, antioxidant activity and sensory attributes of Chokanan mango (Mangifera indica L.) juice. Food and Bioprocess Technology 8: 2256-2267.

Simmonds, M.S.J. 2003. Flavonoid-insect interactions: Recent advances in our knowledge. Phytochemistry 64(1): 21-30.

Srivastava, S., Pathak, N. \& Srivastava, P. 2011. Identification of limiting factors for the optimum growth of Fusarium oxysporum in liquid medium. Toxicology International 18(2): 111-116.

Torres, M.A., Jones, J.D.G. \& Dangl, J.L. 2006. Reactive oxygen species signaling in response to pathogens. Plant Physiology 141(2): 373-378.

Treutter, D. 2006. Significance of flavonoids in plant resistance: a review. Environmental Chemistry Letters 4: 147-157.

Tripathy, B.C. \& Oelmüller, R. 2012. Reactive oxygen species generation and signaling in plants. Plant Signaling \& Behavior 7(12): 1621-1633.

Vishwanath, S., Chandrashekar, S.C., Rajanna, M.D. \& Tejavathi, D.H. 2011. Histopathology of Banana infected with Fusarium oxysporum f. sp. cubense (E. F. Sm.) Synd. \& Hans. Pest Technology 5(1): 63-66.

War, A.R., Paulraj, M.G., Ahmad, T., Buhroo, A.A., Hussain, B., Ignacimuthu, S. \& Sharma, H.C. 2012. Mechanisms of 
plant defense against insect herbivores. Plant Signaling \& Behavior 7(10): 1306-1320.

Xu, G., Liu, D., Chen, J., Ye, X., Ma, Y. \& Shi, J. 2008. Juice components and antioxidant capacity of citrus varieties cultivated in China. Food Chemistry 106(2): 545-551.

Zhang, L., Cenci, A., Rouard, M., Zhang, D., Wang, Y., Tang, Y. \& Zheng, S. 2019. Transcriptomic analysis of resistance and susceptible banana corms in response to infection by Fusarium oxysporum f. sp. cubense tropical race 4. Scientific Reports 9: 8199-8212.
Institute of Biological Sciences \& Centre for Research in Biotechnology for Agriculture (CEBAR)

Faculty of Science

University of Malaya

50603 Kuala Lumpur, Federal Territory

Malaysia

*Corresponding author; email: chandran@um.edu.my

Received: 18 June 2019

Accepted: 24 June 2020 